\title{
Effect of levels of feed intake on plasma concentration and urinary excretion of purine derivatives in crossbred bulls
}

\author{
S.K. George, M.T. Dipu, U.R. Mehra, A.K. Verma ${ }^{1}$ and P. Singh \\ Animal Nutrition Division, Indian Veterinary Research Institute \\ Izatnagar, Uttar Pradesh 243 122, India
}

(Received 21 March 2006; revised version 22 November 2006; accepted 2 February 2007)

\begin{abstract}
The study evaluated the potential of the plasma concentration of purine derivatives (PD) as an alternative to total urine collection method to predict the microbial nitrogen (MN) supply in crossbred bulls. In a completely randomized design, 15 growing crossbred bulls were divided into three groups and assigned three levels (100, 80 and $60 \%$ ) of voluntary dry matter intake (VDMI) on a diet of wheat straw and concentrate mixture (50:50). A metabolism trial of ten days duration was conducted after 90 days of experimental feeding. The daily urinary excretion of allantoin and $\mathrm{PD}$ decreased significantly $(\mathrm{P}<0.01)$ with the reduction in feed intake while creatinine excretion remained similar in animals fed at different levels. The MN supply calculated from the PD excreted in total urine (40.16 to $68.08 \mathrm{~g} / \mathrm{d})$ was higher $(\mathrm{P}<0.01)$ at increased levels of feed intake. The concentration of PD in plasma reflected the differences in MN supply among animals fed at 100 and $80 \%$ of VDMI, while it could not predict the differences in same among animals fed at 80 and $60 \%$ of VDMI. Daily glomerular filtration rate (GFR) was found to be similar in animals fed at 100 and $80 \%$ of VDMI, while there was a fall in GFR, when feed intake was lowered to $60 \%$ of VDMI. The results of this study revealed that, if the plasma concentration of PD is to be used as an index of microbial protein supply, the variation in GFR needs to be considered. Therefore, $\mathrm{PD}$ measurement in total urine is a better indicator of MN supply than the plasma PD concentration.
\end{abstract}

KEY WORDS: crossbred bulls, levels of feed intake, purine derivatives, plasma, urine, microbial nitrogen

\section{INTRODUCTION}

The idea of using purine derivatives (PD) as a specific marker for rumen microbial biomass was suggested by Topps and Elliot (1965). Urinary excretion of

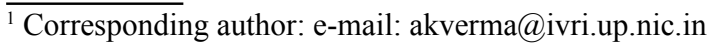


PD (allantoin, uric acid, xanthine and hypoxanthine) has been successfully used to estimate the microbial protein synthesized in the rumen and subsequently digested in the lower gut of ruminants (Chen et al., 1990; Verbic et al., 1990; Dipu et al., 2006). This approach is non-invasive and holds promise as an alternative to existing methods for measuring microbial protein production, which require cannulation of the gut. Application of this technique, however, requires a total collection of urine for several days, and would not be practical under farm conditions. If only blood samples are required, the method can be extended to provide a practical index of microbial protein supply in animals under farm conditions. Chen et al. (1992) demonstrated that plasma PD level could be applicable as a simple index of microbial protein supply in steers, because it was correlated with daily urinary excretion of PD. However, Kagiyama et al. (1996) concluded that plasma allantoin concentration would not be a proper estimator of intestinal flow of microbial protein in calves. In cattle, PD once filtered into the glomerulus, are quantitatively excreted in the urine. There is very little secretion of PD in nephric tubes therefore; the tubular load of PD is dependent on the plasma concentration of PD and glomerular filteration rate. Since PD are not reutilized for the synthesis of purine bases in cattle (Chen et al., 1990), the urinary excretion of PD will be proportional to its plasma concentration, if the clearance and filtration rate of PD are constant. There is a lack of information regarding the relationship of levels of feed intake with plasma concentration and urinary excretion of PD in Indian crossbred cattle. Consequently this study examined the influence of levels of feed intake on urinary PD excretion, concentration of PD in plasma, daily glomerular filtration rate (GFR), tubular load and re-absorption of PD in crossbred bulls.

\section{MATERIAL AND METHODS}

\section{Experimental design, diets, animals and feeding}

Fifteen growing crossbred (Holstein Friesian $\times$ Hariana) bulls ( $>1$ year age and $186.76 \pm 5.38 \mathrm{~kg}$ mean body weight) were used in the study. They were housed in well-ventilated shed with facilities for individual feeding under hygienic and uniform management conditions. The animals were fed a fixed quantity of concentrate mixture ( $2 \mathrm{~kg}$ ) and ad libitum wheat straw individually for one week during the preliminary feeding period. The lowest level of intake recorded during the period among all animals $(4.75 \pm 0.02 \mathrm{~kg} / \mathrm{d}$ on dry matter basis) was set as voluntary dry matter intake (VDMI). The animals were divided into three groups following completely randomization design. The different groups were fed wheat straw and concentrate mixture (50:50) at three fixed levels of VDMI. Highest level 
of feeding at the beginning of the study was $100 \%$ of VDMI (Group I/L-100), determined in the preliminary feeding period. The other levels were $80 \%$ (Group II/L-80) and $60 \%$ (Group III/L-60) of the VDMI. Fresh and clean drinking water was made available ad libitum each day at 10.30 and $14.30 \mathrm{~h}$. The feeding level in each group was increased fortnightly by considering the VDMI of group I (L-100) as $100 \%$. This procedure was followed throughout the experimental period.

\section{Collection period}

A metabolism trial of ten days duration excluding two days of adaptation period was conducted after 90 days of experimental feeding. During trial, the animals were placed in metabolic cages, which facilitate the separate collection of faeces and urine. During the metabolism trial the feeding schedule of the animals remained same as during feeding period and they were fed their respective diet at 9 a.m. daily. Water was made available ad libitum twice daily (10.30 and $14.30 \mathrm{~h}$ ). Representative samples of feed offered, residue left (wheat straw) and faeces voided were brought daily to the laboratory for further chemical analysis. The daily urine was collected into clean plastic containers containing $500 \mathrm{ml}$ of $10 \% \mathrm{H}_{2} \mathrm{SO}_{4}$. The acid was added as preservative ensuring that the final $\mathrm{pH}$ level remained below 3 . At the time of sampling, the $\mathrm{pH}$ of the urine was again checked and adjusted accordingly. During preparation of urine samples, the collected urine samples were filtered using glass wool. A representative urine sample was taken as sub-sample and was mixed thoroughly and $20 \mathrm{ml}$ aliquot was taken in two plastic vials for analysis. The plastic vials were stored at $-20^{\circ} \mathrm{C}$ until analysis. Jugular blood samples $(20 \mathrm{ml})$ were also obtained at the start and finish of the metabolic trial before the animals received their ration in the morning. Blood was equally aliquoted in $10 \mathrm{ml}$-heparinized tubes, centrifuged at $4^{\circ} \mathrm{C}$, and plasma was separated and stored at $-20^{\circ}$ until analysis. The samples of urine and plasma was processed and stored as per the approved protocol (IAEA-TECDOC- 945, 1997).

\section{Measurements and chemical analysis}

The dry matter (DM) and organic matter (OM) contents of feeds and faeces were estimated according to AOAC (1995). PD and creatinine in urine samples were analysed by the HPLC method of Resines et al. (1992) with some modifications (George et al., 2006). Plasma allantoin was determined colorimetrically by the method of Young and Conway (1942). Uric acid in plasma was estimated colorimetrically using a commercial kit $\left(\right.$ Cogent $^{\mathbb{R}}$, India) after hypoxanthine and xanthine were converted to uric acid with xanthine oxidase, according to the procedure of Chen and Gomes (1992). Therefore, 
the plasma uric acid data represents the whole purine derivatives of uric acid, xanthine and hypoxanthine, while total PD is the sum of allantoin, uric acid, xanthine and hypoxanthine. Creatinine in plasma was analysed colourimetrically based on the Jaffe alkaline picrate reaction using a commercial kit (Qualigens ${ }^{\circledR}$, India).

\section{Calculations and statistical analysis}

The amount of microbial purines absorbed (X, mmol/d) corresponding to the PD excreted (Y, mmol/d) was estimated from the predictive model proposed by Singh (2004) in crossbred cattle $\left(\mathrm{Y}=0.83 \mathrm{X}+0.296 \mathrm{~W}^{0.75}\right)$. The slope $(0.83)$ in equation represents the recovery of absorbed purines as PD in urine and the value, 0.296 represents the net endogenous contribution of PD to total excretion.

The supply of microbial nitrogen $(\mathrm{MN}, \mathrm{g} / \mathrm{d})$ was estimated as follows, from the relationship derived by Chen and Gomes (1992):

$$
\mathrm{MN}(\mathrm{g} / \mathrm{d})=70 \mathrm{X} /(0.116 \times 0.83 \times 1000)=0.727 \mathrm{X}
$$

The assumptions made in the above equations are:

- digestibility of microbial purines is assumed to be 0.83 . This is taken as the mean digestibility value for microbial nucleic acids on observations reported in the literature

- the $\mathrm{N}$ content of purines is $70 \mathrm{mg} \mathrm{N} / \mathrm{mmol}$

- the ratio of purine $\mathrm{N}$ : total $\mathrm{N}$ in mixed rumen microbes is taken as 11.6:100.

The supply of MN (g/d) was also estimated as per ARC (1984) based on the assumption that $32 \mathrm{~g} \mathrm{MN}$ is synthesized/kg digestible organic matter fermented in the rumen (DOMR). DOMR was calculated as follows, from the relationship derived by Chen and Gomes (1992):

$\mathrm{DOMR}=$ feed intake $\times$ DM content $(\% / 100) \times \mathrm{OM}$ content $(\% / 100) \times \mathrm{OM}$ digestibility $(\% / 100) \times 0.65$

The GFR (L/d) was calculated from the relationship between urinary creatinine excretion rate and the plasma creatinine concentration [urinary creatinine excretion $(\mathrm{mmol} / \mathrm{d}) /$ plasma creatinine concentration $(\mathrm{mmol} / \mathrm{L})]$. Tubular load of allantoin $(\mathrm{mmol} / \mathrm{d})$ was estimated as the product of GFR and plasma allantoin concentration [GFR $(\mathrm{L} / \mathrm{d}) \times$ plasma allantoin concentration $(\mathrm{mmol} / \mathrm{L})]$ and reabsorption of allantoin $(\mathrm{mmol} / \mathrm{d})$ was estimated as the difference between tubular load of allantoin and allantoin excretion in urine [tubular load of allantoin $(\mathrm{mmol} / \mathrm{d})$ - allantoin excretion in urine $(\mathrm{mmol} / \mathrm{d})$ ] following the procedure described in IAEA-TECDOC-945 (1997). The reabsorbtion percentage of allantoin was also estimated $[100 \times$ reabsorption of allantoin $(\mathrm{mmol} / \mathrm{d}) /$ tubular load of allantoin $(\mathrm{mmol} / \mathrm{d})]$. The same calculation procedures were used in the estimations of tubular load and reabsorption of uric acid and total PD. 
Statistical analysis of all experimental data was performed according to Snedecor and Cochran (1994). A completely randomized design procedure was used in the analysis of variance. The model accounts for variations caused by the levels of feed intake. The tables describe the mean values, SEM and the level of significance of the effects.

\section{RESULTS AND DISCUSSION}

\section{Intake and digestibility}

Composition of the concentrate mixture and wheat straw fed to the animals, determined by chemical analyses is given in Table 1 . The feeds offered did not

Table 1. Chemical composition of concentrate mixture and wheat straw, \% DM

\begin{tabular}{lcc}
\hline Nutrients & Concentrate mixture $^{1}$ & Wheat straw \\
\hline Organic matter & 90.18 & 91.71 \\
Crude protein & 22.98 & 3.10 \\
Ether extract & 3.39 & 0.92 \\
Crude fibre & 8.85 & 38.92 \\
Neutral detergent fibre & 40.07 & 88.68 \\
Acid detergent fibre & 11.07 & 52.95 \\
Total ash & 9.88 & 8.23 \\
\hline
\end{tabular}

${ }^{1}$ parts/100: maize 34.5 , wheat bran 31 , soyabean meal 31 , minerals and vitamins 2.5 , common salt 1

vary through out the experiment, so it has been concluded that the difference observed for digestive events could be attributed to the effects of intake changes. Table 2 gives the values for mean body weight, feed intake (DM and OM) and the apparent digestibility of DM and OM. The DM and OM intakes were significantly different $(\mathrm{P}<0.01)$ among the treatment groups as envisaged by the experimental design. The total DM consumption $(\mathrm{kg} / \mathrm{d})$ ranged from 3.24 in group III to 5.34 in group I. The digestibility of DM was lower $(\mathrm{P}<0.05)$ in group III while that of OM was similar among the groups. It has been suggested that the digestibility of feed is not a fixed trait but is modified by factors such as the level of feed intake (Blummel et al., 2003), age and stage of production. Restriction of feed intake often results in enhanced DM and OM digestibility owing to higher retention time in the rumen (Galyean and Owens, 1991). However, in the present study, decrease in feed intake lowered the DM and OM digestibility and this is probably due to lower availability of energy which limits the growth of microorganisms. 
Table 2. Mean body weight, DM intake, digestible DM (DDM) intake, OM intake, digestible OM (DOM) intake, Digestible organic matter fermented in the rumen (DOMR) and apparent digestibility of DM and OM in different groups

\begin{tabular}{lcccc}
\hline \multirow{2}{*}{ Parameters } & Group I & Group II & Group III & \multirow{2}{*}{ SEM } \\
\cline { 2 - 4 } & L-100 & L-80 & L-60 & \\
\hline Body weight, kg & 217.40 & 212.84 & 206.68 & 14.07 \\
Intake, kg/d & & & & \\
$\mathrm{DM}^{* *}$ & $5.34^{\mathrm{a}}$ & $4.32^{\mathrm{b}}$ & $3.24^{\mathrm{c}}$ & 0.05 \\
$\mathrm{DDM}^{* *}$ & $3.26^{\mathrm{a}}$ & $2.62^{\mathrm{b}}$ & $1.83^{\mathrm{c}}$ & 0.06 \\
$\mathrm{OM}^{* *}$ & $4.86^{\mathrm{a}}$ & $3.93^{\mathrm{b}}$ & $2.95^{\mathrm{c}}$ & 0.04 \\
DOM $^{* *}$ & $3.06^{\mathrm{a}}$ & $2.45^{\mathrm{b}}$ & $1.77^{\mathrm{c}}$ & 0.07 \\
DOMR, kg/d $^{* *}$ & $1.99^{\mathrm{a}}$ & $1.59^{\mathrm{b}}$ & $1.15^{\mathrm{c}}$ & 0.04 \\
Digestibility, \% & & & & \\
DM & & & & \\
OM & $60.92^{\mathrm{a}}$ & $60.70^{\mathrm{a}}$ & $56.67^{\mathrm{b}}$ & 1.16 \\
\hline
\end{tabular}

values within a row with different superscripts are significantly different, ${ }^{*} \mathrm{P}<0.05,{ }^{* *}(\mathrm{P}<0.01)$

\section{Purine derivatives and creatinine in urine and plasma at different levels of feed intake}

Microbial protein synthesis is dependent on digestible organic matter intake and ammonia nitrogen supply. When feed is identical qualitatively, the efficiency of microbial growth will obviously depend upon the level of intake. In this experiment, three levels of feed intake were adopted to create a range of daily MN supply under a variety of practical feeding conditions. Dietary treatments had strong $(\mathrm{P}<0.01)$ influence in the urinary out put of PD (Table 3$)$. The mean PD excretion observed in urine was similar to the values reported (53.7 to 104.4 $\mathrm{mmol} / \mathrm{d}$ ) in crossbred heifers fed barley straw and concentrate mixture (Martin Orue et al., 2000). Allantoin accounted above $90 \%$ of the total urinary PD excreted and thus corroborated well with the findings of Verbic et al. (1990).

The plasma allantoin concentration was higher in group I compared to the lower levels of feed intake (Table 3). The mean plasma level $(\mu \mathrm{mol} / \mathrm{L})$ of allantoin recorded in the present experiment was higher than the value (184.5 $\mu \mathrm{mol} / \mathrm{L}$ ) reported for European cattle (Giesecke et al., 1994). The higher plasma allantoin concentration in crossbred bulls may be due to a higher absorption rate of microbial purines from the small intestine into the circulatory system or a lower recycling into the rumen, which might be due to higher activity of xanthine oxidase in plasma, resulting in the complete conversion of absorbed microbial purines to end products (PD). This is further confirmed by the absence of salvageable PD (xanthine and hypoxanthine) in the urine of cattle. The 
Table 3. Purine derivatives (PD) and creatinine in urine and plasma, daily glomerular filtration rate (GFR), tubular load, re-absorption of PD and microbial nitrogen (MN) supply at different levels of feed intake

\begin{tabular}{|c|c|c|c|c|}
\hline \multirow{2}{*}{ Parameters } & Group I & Group II & Group III & \multirow{2}{*}{ SEM } \\
\hline & L-100 & $\mathrm{L}-80$ & L-60 & \\
\hline \multicolumn{5}{|l|}{ Urine, $\mathrm{mmol} / \mathrm{d}$} \\
\hline allantoin** & $86.65^{\mathrm{a}}$ & $71.68^{b}$ & $55.34^{\mathrm{c}}$ & 4.14 \\
\hline uric acid & 7.82 & 6.76 & 6.64 & 1.24 \\
\hline $\mathrm{PD}^{* *}$ & $94.47^{\mathrm{a}}$ & $78.44^{\mathrm{b}}$ & $61.98^{\mathrm{c}}$ & 4.57 \\
\hline creatinine & 65.68 & 65.40 & 57.13 & 5.82 \\
\hline \multicolumn{5}{|l|}{ Plasma, $\mu \mathrm{mol} / \mathrm{L}$} \\
\hline allantoin** & $290.43^{\mathrm{a}}$ & $239.08^{b}$ & $239.64^{\mathrm{b}}$ & 14.25 \\
\hline uric acid & 26.74 & 26.13 & 23.77 & 2.36 \\
\hline $\mathrm{PD}^{* *}$ & $317.17^{\mathrm{a}}$ & $265.21^{\mathrm{b}}$ & $263.40^{\mathrm{b}}$ & 15.56 \\
\hline creatinine & 85.94 & 84.09 & 89.17 & 4.70 \\
\hline GFR, L/d* & $768.17^{\mathrm{a}}$ & $771.72^{\mathrm{a}}$ & $639.86^{\mathrm{b}}$ & 46.62 \\
\hline \multicolumn{5}{|l|}{ Tubular load, mmol/d } \\
\hline allantoin* & $222.59^{\mathrm{a}}$ & $184.45^{\mathrm{b}}$ & $154.00^{\mathrm{b}}$ & 16.22 \\
\hline uric acid & $20.48^{\mathrm{a}}$ & $20.23^{\mathrm{a}}$ & $15.21^{\mathrm{b}}$ & 2.25 \\
\hline $\mathrm{PD}^{* *}$ & $243.07^{\mathrm{a}}$ & $204.67^{\mathrm{ab}}$ & $169.21^{\mathrm{b}}$ & 17.87 \\
\hline \multicolumn{5}{|l|}{ Re-absorption, $\mathrm{mmol} / \mathrm{d}$} \\
\hline allantoin* & $135.94^{\mathrm{a}}$ & $112.77^{\mathrm{ab}}$ & $98.66^{\mathrm{b}}$ & 15.18 \\
\hline uric acid & 12.66 & 13.47 & 8.58 & 2.47 \\
\hline $\mathrm{PD}^{* *}$ & $148.60^{\mathrm{a}}$ & $126.23^{\mathrm{ab}}$ & $107.23^{b}$ & 17.07 \\
\hline \multicolumn{5}{|l|}{ Re-absorption, \% } \\
\hline allantoin & 60.90 & 60.53 & 63.47 & 3.12 \\
\hline uric acid & 61.39 & 64.82 & 56.00 & 8.01 \\
\hline PD & 60.94 & 61.00 & 62.74 & 3.36 \\
\hline \multicolumn{5}{|l|}{ MN supply, gN/d } \\
\hline based on urinary $\mathrm{PD}^{* *}$ & $68.08^{\mathrm{a}}$ & $54.28^{\mathrm{b}}$ & $40.16^{\mathrm{c}}$ & 3.49 \\
\hline based on DOMR** & $63.74^{\mathrm{a}}$ & $50.92^{\mathrm{b}}$ & $36.83^{\mathrm{c}}$ & 1.37 \\
\hline
\end{tabular}

values within a row with different superscripts are significantly different, $* \mathrm{P}<0.05, * * \mathrm{P}<0.01$

concentration of uric acid in plasma was similar among the groups and was comparable to the previous reports (Geisecke et al., 1994). The molar ratio of plasma PD followed a similar pattern as that of urine with allantoin accounted above $90 \%$ of total. However, the plasma level of PD (Y, $\mu \mathrm{mol} / \mathrm{L})$ was poorly correlated with urinary $\mathrm{PD}(\mathrm{X}, \mathrm{mmol} / \mathrm{d})$ :

$$
\begin{gathered}
\mathrm{Y}=172.13( \pm 38.97)+1.40( \pm 0.50) \mathrm{X} \\
(\mathrm{r}=0.62 ; \mathrm{n}=15 ; \mathrm{P}<0.05)
\end{gathered}
$$


Brody (1945) stated that, for animals of different sizes of the same species, creatinine excretion is directly proportional to body weight. Moreover, the use of creatinine as an internal marker of urinary out put relies on the assumption that the creatinine excretion through urine is affected neither by diet nor the physiological status of the animal, but is excreted in proportion to body weight. Urinary creatinine concentration measured in this study was not affected by dietary treatments and thus reaffirmed the above statements. There was no much difference in the body weight of the animals used in this study and they had similar excretion of urinary creatinine. The daily mean urinary creatinine excretion observed was lower than previous reports of between 112 to $117 \mathrm{mmol} / \mathrm{d}$ in European cattle (Puchala et al., 1993). It is conceivable that between breed/species differences in musculature and variations in body weight could account for these discrepancies. However, the plasma concentration of creatinine observed in this study corroborated well with the values reported in Bali ( 87.9 to $102.7 \mu \mathrm{mol} / \mathrm{L}$ ) and Ongole cattle ( 81.8 to 98.2 $\mu \mathrm{mol} / \mathrm{L}$ ) fed at different levels of intake (Soejono et al., 1999).

Microbial nitrogen supply, glomerular filtration rate, tubular load and reabsorption of purine derivatives

MN (g/d) supply estimated from urinary excretion of PD and from DOMR is summarized in Table 3. Mean values of MN estimated using both the methods was significantly $(\mathrm{P}<0.01)$ affected by feed intake. The efficiency of $\mathrm{MN}$ synthesized, calculated based on urinary $\mathrm{PD}$, ranged between 30.2 and $39.5 \mathrm{~g} / \mathrm{kg}$ DOMR although the mean of these values (34.4 g/ $\mathrm{kg}$ DOMR) was slightly higher than the value (32 $\mathrm{g} / \mathrm{kg}$ DOMR) adopted by the ARC (1984). MN calculated based on DOMR ( $\mathrm{Y}, \mathrm{g} / \mathrm{d})$ was correlated with the urinary PD (X, $\mathrm{mmol} / \mathrm{d})$ as follows:

$$
\mathrm{Y}=-3.95( \pm 6.57)+0.70( \pm 0.08) \mathrm{X} ;(\mathrm{r}=0.92 ; \mathrm{n}=15 ; \mathrm{P}<0.001)
$$

MN calculated based on DOMR (Y, g/d) was also correlated with plasma PD $(\mathrm{X}, \mu \mathrm{mol} / \mathrm{L})$, but the correlation coefficient was much lower.

$$
\mathrm{Y}=-12.04( \pm 19.83)+0.22( \pm 0.70) \mathrm{X} ;(\mathrm{r}=0.66 ; \mathrm{n}=15 ; \mathrm{P}<0.05)
$$

GFR was calculated in the present study as the ratio between daily urinary creatinine excretion and plasma creatinine concentration (IAEA-TECDOC-945, 1997). The estimated GFR was comparable to the previous reports (602 to 835 L/d) in Bali and Ongole cattle (Soejono et al., 1999). GFR (Y, L/d) was correlated with DMI (X, kg/d) as follows:

$$
\mathrm{Y}=449.22( \pm 100.05)+64.51( \pm 22.81) \mathrm{X} ;(\mathrm{r}=0.62 ; \mathrm{n}=15 ; \mathrm{P}<0.05)
$$

In the present study, the plasma level of PD was poorly correlated (0.62) with urinary PD. However, the product of GFR and plasma PD concentration, i.e. 
the tubular load (Y, mmol/d) of PD, had a better correlation with the daily PD excretion $(\mathrm{X}, \mathrm{mmol} / \mathrm{d})$ :

$$
\mathrm{Y}=44.25( \pm 37.38)+2.06( \pm 0.47) \mathrm{X} ;(\mathrm{r}=0.77 ; \mathrm{n}=15 ; \mathrm{P}<0.01)
$$

The relationship between plasma $\mathrm{PD}$ level and urinary excretion of $\mathrm{PD}$ has been investigated by a number of workers (Chen et al., 1992; Giesecke et al., 1994; Fujihara et al., 2003). However, the results on whether plasma PD concentration was correlated with daily urinary PD output were inconsistent. It has been reported that, the urinary excretion of $\mathrm{PD}$ is proportional to the plasma concentration of PD and GFR (Chen and Ørskov, 2003). If GFR is constant, then concentration of PD in plasma is linearly correlated with the influx of microbial purines from the intestines. However, if GFR and reabsorption of PD is variable, plasma level of PD will be related with neither the influx into the plasma nor the renal excretion. At increased levels of feed intake the influx will be obviously high. Therefore, if GFR is not changing with feed intake, the plasma PD can be used as an index of microbial protein supply. The studies conducted in (Chen et al., 1995) European cattle and sheep (Kagiyama et al., 1996) revealed that the GFR in same animal may change with feed intake. However, in the current study in crossbred bulls, GFR was found to be similar in animals fed 100 and $80 \%$ of VDMI, while there was a fall $(\mathrm{P}<0.05)$ in GFR, when feed intake was lowered to $60 \%$ of VDMI. Therefore, the plasma concentration of PD reflected the differences in MN supply among animals fed at 100 and $80 \%$ of VDMI, while it could not predict the differences in same among animals fed at 80 and $60 \%$ of VDMI (Table $3)$. This indicates that, when feed intake is very low ( $60 \%$ of VDMI), the GFR is reduced to maintain a minimum level of plasma PD concentration. Indeed, in this experiment, the correlation between plasma PD and daily PD excretion was improved ( $\mathrm{r}$ increased from 0.62 to 0.77 ) after correcting for GFR (i.e. by multiplying the PD concentration by GFR) as also observed in sheep fed at four different levels (Chen et al., 1995)

\section{CONCLUSIONS}

From the results obtained in the present study it can be concluded that, if the plasma concentration is to be used to indicate the flow of microbial purines into the blood or the excretion of PD in urine, the variation in GFR needs to be taken into account. Therefore, the authors consider PD measurement in total urine to be a better parameter than plasma $\mathrm{PD}$ as an indicator of microbial nitrogen supply in crossbred bulls. 


\section{ACKNOWLEDGEMENTS}

The authors are thankful to the NATP(CGP-III), ICAR, New Delhi for providing financial assistance for this study. The first author is indebted to UGC, New Delhi for providing financial assistance in the form of junior research fellowship.

\section{REFERENCES}

AOAC, 1995. Association of Official Analytical Chemists, Official Methods of Analyses. $16^{\text {th }}$ Edition. Washington, DC

ARC, 1984. The Nutrient Requirements of Ruminant Livestock, No. 1. Commonwealth Agricultural Bureaux, pp. 3-18

Blummel M., Zerbini E., Reddy B.V.S., Hash C.T., Bidinger F., Ravi D., 2003. Improving the production and utilization of sorghum and pearl millet as livestock feed: methodological problems and solutions. Field Crops Res. 84, 123-142

Brody S., 1945. Bioenergetics and Growth. Reinhold, New York

Chen X.B., Gomes M.J., 1992. Estimation of microbial protein supply to sheep and cattle based on urinary excretion of purine derivatives: An overview of the technical details. The Rowett Research Institute, University of Aberdeen (UK)

Chen X.B., Grubic G., Ørskov E.R., Osuji P., 1992. Effect of feeding frequency on diurnal variation in plasma and urinary purine derivatives in steers. Anim. Prod. 55, 185-191

Chen X.B., Mejia A.T., Kyle D.J., Ørskov E.R., 1995. Evaluation of the use of the purine derivative: creatinine ratio in spot urine and plasma samples as an index of microbial protein supply in ruminants: studies in sheep. J. Agr. Sci. 125, 137-143

Chen X.B., Ørskov E.R., 2003. Research on urinary excretion of purine derivatives in ruminants: past, present and future. In: H.P.S. Makkar (Editor). Development, Standardization and Validation of Nuclear-Based Technologies for Estimating Microbial Protein Supply in Ruminant Livestock for Improving Productivity. IAEA-2003, Vienna, pp.15

Chen X.B., Ørskov E.R., Hovell F.D., 1990. Excretion of purine derivatives by ruminants: endogenous excretion differences between cattle and sheep. Brit. J. Nutr. 63, 121-129

Dipu M.T., George S.K., Singh P., Verma A.K., Mehra U.R., 2006. Measurement of microbial protein supply in Murrah buffaloes (Bubalus bubalis) using urinary purine derivatives excretion and PDC index. Asian-Austr. J. Anim. Sci. 19, 347-355

Fujihara T., Iwakuni M., Shem M.N., Hirano T., 2003. The effect of rumen protozoa on plasma allantoin level and urinary excretion of purine derivatives in sheep. J. Anim. Feed. Sci. 12, 499511

Galyean M.L., Owens F.N., 1991. Effects of diet composition and level of feed intake on site and extent of digestion in ruminants. In: T. Tsuada, Y. Sasaki, R. Kawashima (Editors). Physiological Aspect of Digestion and Metabolism in Ruminants. Academic Press, San Diego, pp. 483-514

George S.K., Dipu M.T., Mehra U.R., Singh P., Verma A.K., Ramgaokar J.S., 2006. Improved HPLC method for the simultaneous determination of allantoin, uric acid and creatinine in cattle urine. J. Chromatogr. B 832, 134-137

Giesecke D., Ehrentreich L., Stangassinger M., 1994. Mammary and renal excretion of purine metabolites in relation to energy intake and milk yield in dairy cows. J. Dairy Sci. 77, 23762381 
IAEA-TECDOC-945, 1997. Estimation of Rumen Microbial Protein Production from Purine Derivatives in Urine. International Atomic Energy Agency, Vienna

Kagiyama R., Funaba M., Iriki T., Abe M., 1996. Plasma allantoin concentration in response to changes in nutritional status of calves. Asian-Austr. J. Anim. Sci. 9, 165-170

Martin Orue S.M., Balcells J., Gauda J.A., Fondevila M., 2000. Microbial nitrogen production in growing heifers: direct measurement of duodenal flow purine bases versus urinary excretion of purine derivatives as estimation procedures. Anim. Feed Sci. Tech. 88, 171-188

Puchala R., Shelford J.A., Barej W., Kulasek G.W., Pior H., Keyserlingk M.V., Makoni N., 1993. Urinary excretion of psuedouridine and purine metabolites in ruminants. J. Anim. Physiol. Anim. Nutr. 69, 186-193

Resines J.E., Arin M.J., Diez M.T., 1992. Determination of creatinine and purine derivatives in ruminants urine by reversesed phase high performance liquid chromatography. J. Chromatogr. 607, 199-202

Singh M., 2004. Prediction of microbial protein production from urinary excretion of purine derivatives in crossbred cattle. MVSc. Thesis. Deemed University, IVRI, Izatnagar (India)

Snedecor G.W., Cochran W.G., 1994. Statistical Methods. $8^{\text {th }}$ Edition. Iowa State University, Iowa

Soejono M., Yusiati L.M., Budhi S.P.S., Widyobroto B.P., 1999. Estimating rumen microbial protein supply for indigenous ruminants using nuclear and purine excretion techniques in Indonesia. IAEA- TECDOC- 1093, pp. 43-58

Topps J.H., Elliot R.C., 1965. Relationships between concentrations of ruminal nucleic acid and excretion of purine derivatives by sheep. Nature 205, 498-499

Verbic J., Chen X.B., MacLeod N.A., Ørskov E.R., 1990. Excretion of purine derivatives by ruminants: effects of microbial nucleic acids infusion on purine derivative excretion by steers. J. Agr. Sci. 114, 243-248

Young E.G., Conway C.F., 1942. On the estimation of allantoin by Rimini-Schryver reaction. J. Biol. Chem. 142, 839-852 